\title{
Food Waste in Catering Establishments - An Analysis of Causes and Consequences
}

\author{
By Marzena Tomaszewska ${ }^{1}$, Beata Bilska ${ }^{1}$, Danuta Kołożyn-Krajewska ${ }^{1}$
}

\begin{abstract}
Food waste and food loss covers the entire food chain, and its scale varies depending on the given part of the chain. The aim of this study was to identify causes of food waste in the catering sector. The research was carried out in catering establishments using a specially designed questionnaire. The study was conducted in Mazowieckie Voivodship (Poland) in 2019. Forty-two questionnaires were collected. The scoring of most questions was based on a 5-point scale (e.g. 1 - never to 5 -always). It was found that the most frequently wasted products in catering establishments were those with signs of deterioration or that were expired $(29 \%$ and $26.3 \%$ of respondents respectively indicated that this type of product is discarded every day). Ready elements of dishes, e.g. cooked potatoes or boiled rice that have not been served to consumers are rarely reused in the catering sector. The most frequently given reason for throwing out food included preparing too many meals, purchases that were too large, and ill-considered purchases. The results of this study may play an important role in the prevention of food waste in catering establishments by indicating which areas of employee practices should be improved by educational activities.
\end{abstract}

Keywords: food waste, causes of food waste, food service sector, waste of bread, waste of fruit and vegetables.

\section{Introduction}

Food loss and food waste are a common problem of the modern world. They are considered to be a serious risk to food safety and to the environment. Every year, about one third of the food produced for human consumption (1.3 bn tons of food) is lost and wasted in the whole supply chain (Gustavsson et al. 2011). As Ishangulyyev et al. (2019) emphasise, defining food loss and food waste is problematic because the terms are often used interchangeably. These concepts can be used though to describe different phenomena. According to the definitions offered by the the Food and Agriculture Organization of the United Nations (FAO), "Food Loss" is a "decrease in weight (dry matter) or quality (nutritional value) of food that was originally produced for human consumption" and "Food Waste" is "Food appropriate for human consumption being discarded, whether after it is left to spoil or kept beyond its expiry date." Losses result from mismanagement and flaws in the course of production, agricultural harvesting, processing, transport, and production plant storage. Waste occurs when there are irregularities in the transport, distribution, storage and processing of food designated for consumption in households and catering establishments (Gustavsson et al. 2011).

Food is wasted first and foremost at the retail and consumer levels in medium and high income countries. As cited by (Save Food: Global ...) every year, consumers in rich 
countries waste almost as much food (222 million tons) as the entire net food production of sub-Saharan Africa (230 million tons). Per capita waste by consumers is between 95$115 \mathrm{~kg}$ a year in Europe and North America, while consumers in sub-Saharan Africa, South and Southeast Asia, each throw away only $6-11 \mathrm{~kg}$ a year.

Such a huge scale of food loss and food waste has led to a number of measures that are taken these days to reduce these at every stage of the food chain. Responsible consumption and production have been clearly emphasised in the 2015-2030 Agenda for Sustainable Development, as one of seventeen Sustainable Development Goals adopted by the UN General Assembly. It was underscored that the development of adequate instruments to reduce the use of natural resources is essential (United Nations. Sustainable Development Goals). Food loss and food waste decrease is a measure that has a real impact on the production scale in the food and agriculture sectors, and at the same time, the use of natural resources. The research undertaken aimed to demonstrate main reasons for food waste in catering establishment. The research was conducted in catering establishments for the following reasons:

(1) In Poland, the service sector has grown dynamically over the last few years (Maciag et al. 2018). As Gheribi (2014) notes, there has been a considerable growth in demand for services connected with forms of spending leisure, which includes, among other things, catering services. According to Pirani \& Arafat (2016), the catering sector expansion is connected with increased amounts of generated waste, including food waste.

(2) The catering service sector, together with distribution and trade, are classified as third (following households and food production) in terms of the amount of food wasted.

(3) The issue of food waste is discussed in merely a few scientific studies, which is also noted by Pirani \& Arafat (2016). There is a clearly higher number of papers concerning the problem of food waste in households, e.g. Stancu et al. (2016), Berjan S. et al. (2019).

\section{Material and Methodology}

\subsection{Research design}

A survey study was conducted in the first half of 2019. The selection of catering establishments was deliberate. This establishments were located only in Mazowieckie Voivodeship (Poland). The pilot test was conducted with one catering establishment in Warsaw. The revised version of questionnaire was divided into following parts: a demographic section, procedures for procurement and storage, and procedures relating to the production process and shipping, in the context of food waste. 42 completed questionnaires were collected.

\subsection{Data collection}

The surveys were delivered personally to catering establishments by the research authors. Research aims were presented on site. If an establishment owner or establishment manager agreed to participate in the research, instructions were given how to complete the survey and it was then left there. Every owner/manager filled in the survey within an individually chosen time frame. After one week, the survey was collected by the person that delivered it. In some questions, answers were based on a 5-point scale of 1 to 5 (from "always" / "every day" to "never"). The survey also included closed questions with a 
suggested cafeteria of answers.

\subsection{Data analysis}

In discussing the results, such elements of descriptive statistics as mean, median, mode, kurtosis and standard deviation (SD) were used. The percentage share of correct answers was calculated. All tests were made using Statistica 12 software.

\section{Results}

\subsection{Characteristics of the surveyed establishments}

The characteristics of establishments are given in Table 1. They included mostly restaurants operating on the market longer than nine years and employing maximum 20 people.

The surveyed establishments served an average of 190 on a daily basis (a range from 30 to 1500 people). The majority of establishments served daily up to 100 consumers.

Table 1: Characteristics of the catering establishments participating in the study (\%)

\begin{tabular}{|l|c|c|}
\hline Characteristics & Categories & \% \\
\hline Type of establishment: & Bar & 4.8 \\
& Restaurant & 52.4 \\
& Hotel catering & 19.0 \\
& Canteen & 0 \\
& Catering point & 2.4 \\
& Café & 11.9 \\
& Other & 9.5 \\
\hline Length of business operation: & $<1$ year & 4.7 \\
& $1-2$ years & 11.9 \\
& $3-5$ years & 26.2 \\
& $6-5$ years & 16.7 \\
& $>9$ years & 40.5 \\
\hline Number of employees: & up to 10 & 23.8 \\
& $11-20$ & 38.1 \\
& $21-50$ & 16.7 \\
& $51-70$ & 4.7 \\
& More than 70 & 16.7 \\
\hline Number of consumers served: & up to 100 & 47.6 \\
& $101-200$ & 30.9 \\
& $201-400$ & 16.7 \\
& More than 400 & 4.8 \\
\hline
\end{tabular}

\subsection{Practices used in catering establishments within the context of food waste}

The practices determined by respondents as applied in the catering establishments rather did not contribute to the phenomenon of food waste (Table 2). The prevalence of undesirable behaviours that could potentially lead to food waste (in a wider context) were found at the level of procurement. Employees responsible for procurement were especially unwilling to buy misshapen and small fruit and vegetables, and products in deformed packaging (in which packaging barrier was not broken). 
Table 2: Practices used in catering establishments within the context of food waste

\begin{tabular}{|c|c|c|c|}
\hline Stage & Frequency of listed actions & $\begin{array}{l}\text { Procedures } \\
\text { reducing food } \\
\text { waste } \\
(\% \text { of answers })\end{array}$ & $\begin{array}{l}\text { Procedures } \\
\text { increasing food } \\
\text { waste } \\
(\% \text { of answers })\end{array}$ \\
\hline \multirow{5}{*}{ 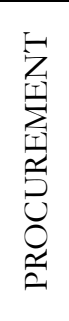 } & Inspecting stock levels $(n=42)^{(a)}$ & 97.6 & 2.4 \\
\hline & Preparing lists of necessary products $(n=42)^{(a)}$ & 95.2 & 4.8 \\
\hline & $\begin{array}{l}\text { Purchasing/receiving small, misshapen and } \\
\text { deformed fruit and vegetables }(n=42) \text { (a) }\end{array}$ & 4.8 & 95.2 \\
\hline & $\begin{array}{l}\text { Purchasing/receiving products with very short } \\
\text { expiry dates }(n=42) \text { (b) }\end{array}$ & 95.2 & 4.8 \\
\hline & $\begin{array}{l}\text { Purchasing/receiving products in deformed } \\
\text { packaging }(\mathrm{n}=42)^{(\mathrm{a})}\end{array}$ & 0 & 100 \\
\hline \multirow{4}{*}{ 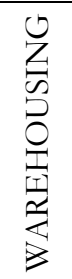 } & Inspecting shelf life dates $(n=42)^{(c)}$ & 90.6 & 9.5 \\
\hline & Inspecting condition of packaging $(n=42)^{(c)}$ & 73.8 & 26.2 \\
\hline & $\begin{array}{l}\text { Inspecting appearance and smell of unwrapped } \\
\text { products }(n=42)^{(c)}\end{array}$ & 90.5 & 9.5 \\
\hline & $\begin{array}{l}\text { Storing unprocessed raw materials (raw meat, } \\
\text { vegetables) and finished products in the same } \\
\text { refrigerator }(n=42)^{(b)}\end{array}$ & 85.7 & 14.3 \\
\hline \multirow{3}{*}{ 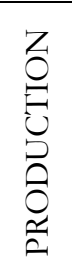 } & $\begin{array}{l}\text { Using the same small equipment (with no additional } \\
\text { treatment) for cutting various groups of products } \\
(\mathrm{n}=42)^{(\mathrm{b})}\end{array}$ & 83.3 & 16.7 \\
\hline & $\begin{array}{l}\text { Refreezing unused raw materials which have been } \\
\text { previously defrosted, e.g. meat }(n=33) \text { (b) }\end{array}$ & 90.9 & 9.1 \\
\hline & $\begin{array}{l}\text { Labelling ready goods which have been prepared in } \\
\text { advance with production dates }(n=21)^{(a)}\end{array}$ & 90.5 & 9.5 \\
\hline
\end{tabular}

a) answers based on a scale of "always" to "never" (procedure reducing food waste: always, usually), b) answers based on a scale of "always" to "never" (procedure reducing food waste: sometimes, occasionally, never),

c) answers from "more often than $2 x$ daily" to "never" (procedure reducing food waste: more often than $2 x$ daily, $2 x$ daily, $1 x$ daily, 2-3x weekly)

As the respondents stated, when stored, product expiry dates, packaging condition, appearance and smell of unwrapped products were inspected rather regularly (the answer of 'once a day' was the most frequent). A vast majority of those surveyed indicated that their workplaces followed a basic rule of storing raw materials and finished products separately. Procedures applied during the production process itself did not give rise to any serious reservations either. There was an insubstantial number of inappropriate practices reported connected with, for example, the defrosting of products and hygiene of small equipment used for production.

\subsection{Products most often wasted in catering}

The respondents said that in their workplaces, it is products which have already been opened and show signs of spoilage that are most frequently thrown away (mean = 2.84) (Table 3). It is particularly this kind of products that form a category of food in the case of which as much as $28 \%$ of the respondents (mode \%) said that they discard some 
every day (mode $=1.0$ ). Responses of a considerably wide scope (negative values of kurtosis) were given in regard to discarding started products that show signs of spoilage (kurtosis $=-1.293$ ) and products past their expiry dates (kurtosis $=-1.145$ ). The surveyed said that intermediate products such as breaded raw meat (mean $=3.63$ ) and opened products with no signs of spoilage (mean $=3.51$ ) were least often thrown away in their workplaces. Overwhelmingly, it was opened products with no signs of spoilage in the case of which $1 / 3$ of respondents said that products of this kind are never discarded in their work establishments $($ mode $=5.0$, mode $\%=33.3$ ).

The catering establishments employees pointed that in their workplaces, dishes served cold and hot ready meals are discarded every day or almost every day $(23.7 \%$ and $20.5 \%$ of answers respectively) (Table 3). It was determined that the food most often thrown away is raw vegetable salads and cooked salads (27.6\% of answers) as well as dishes made of vegetables $(23.3 \%$ of responses) (Table 4$)$. Meals not served to consumers were most frequently storage in refrigerator condition to next day.

\subsection{Reasons for food waste in catering}

The respondents stated that a reason why food is discarded in their workplaces is first and foremost preparing too much food (Table 5). Almost 1/4 of those surveyed said that food is thrown away "always" or "usually" because of the above. Yet a negative and relatively high value of kurtosis (-1.397) means that the replies given were often radical. As the least often cited reason for discarding food, the respondents cited the following: lack of ideas for using products for preparing other meals (mode $=5.0$, $\operatorname{mode} \%=74.4$ ), purchasing products of low quality (mode $=5.0$, mode $\%=56.4$ ).

In the research, $1 / 5$ of catering establishments employees indicated that clients "always" or "usually" leave uneaten meals on their plates, and over $41 \%$ (mode $\%$ ) "sometimes" do so. At the same time, consumers seldom order half-portion meals (mode $=5.0$, mode $\%$ = 47.5) (Table 6).

Table 3: Descriptive statistics results concerning products most frequently discarded in catering establishments as indicated by the respondents

\begin{tabular}{|l|c|c|c|c|c|c|c|c|}
\hline Discarded products & $\mathrm{N}$ & $\begin{array}{c}\text { Every day } \\
\text { and almost } \\
\text { every day (\%) }\end{array}$ & Mean & Median & Mode & Mode \% & Kurtosis & SD \\
\hline $\begin{array}{l}\text { Intermediary products, e.g. raw } \\
\text { products, breaded meat }\end{array}$ & 38 & 15.8 & 3.63 & 4.0 & 4.0 & 36.8 & -0.036 & 1.32 \\
\hline $\begin{array}{l}\text { Meals served cold (green salads, } \\
\text { raw vegetable salads) }\end{array}$ & 38 & 23.7 & 3.18 & 3.0 & 3.0 & 38.8 & -0.448 & 1.16 \\
\hline Hot dishes & 39 & 20.5 & 3.46 & 4.0 & 4.0 & 30.8 & -0.624 & 1.35 \\
\hline Bread & 38 & 21.2 & 3.39 & 3.5 & 3.0 & 28.9 & -0.772 & 1.37 \\
\hline Wilted fruit and vegetables & 40 & 27.5 & 2.95 & 3.0 & 3.0 & 42.5 & -0.693 & 1.23 \\
\hline Products past their expiry dates & 38 & 31.6 & 2.84 & 3.0 & $\begin{array}{l}\text { repeated: } \\
\text { accordingly: }\end{array}$ & -1.145 & 1.28 \\
\hline $\begin{array}{l}\text { Opened products with signs } \\
\text { of spoilage }\end{array}$ & 38 & 42.2 & 2.65 & 3.0 & 1.0 & 28.9 & -1.293 & 1.30 \\
\hline $\begin{array}{l}\text { Opened products with no } \\
\text { signs of spoilage }\end{array}$ & 39 & 25.7 & 3.51 & 4.0 & 5.0 & 33.3 & -0.979 & 1.45 \\
\hline
\end{tabular}

1- every day, 2 - almost every day, 3 - sometimes, 4 - occasionally, 5 - never 
Table 4: Method of handling ready meals not served to customers on the day of their preparation in catering establishments (\%)

\begin{tabular}{|l|c|c|c|c|c|c|c|}
\hline $\begin{array}{l}\text { Method of } \\
\text { handling }\end{array}$ & $\begin{array}{c}\text { Raw } \\
\text { vegetable } \\
\text { salads, green } \\
\text { salads } \\
(\mathrm{n}=29)\end{array}$ & $\begin{array}{c}\text { Appetizers } \\
\text { served cold } \\
\text { and/or hot } \\
(\mathrm{n}=39)\end{array}$ & $\begin{array}{c}\text { Soups, } \\
\text { stocks, } \\
\text { gravies } \\
(\mathrm{n}=35)\end{array}$ & $\begin{array}{c}\text { Dishes of } \\
\text { meat, } \\
\text { poultry, } \\
\text { fish } \\
(\mathrm{n}=36)\end{array}$ & $\begin{array}{c}\text { Dishes } \\
\text { of offal } \\
(\mathrm{n}=20)\end{array}$ & $\begin{array}{c}\text { Dishes of } \\
\text { greens, } \\
\text { potatoes and } \\
\text { vegetables } \\
\text { (n=30) }\end{array}$ & $\begin{array}{c}\text { Flour- } \\
\text { based } \\
\text { dishes } \\
(\mathrm{n}=31)\end{array}$ \\
\hline Not applicable & 31.0 & 7.1 & 16.7 & 14.3 & 47.6 & 28.6 & 26.2 \\
\hline Freezing & 0.0 & 2.6 & 5.7 & 5.6 & 15.0 & 10.0 & 9.7 \\
\hline $\begin{array}{l}\text { Storing in fridge } \\
\text { until the following } \\
\text { day }\end{array}$ & 48.3 & 43.6 & 57.1 & 55.6 & 40.0 & 46.7 & 48.4 \\
\hline $\begin{array}{l}\text { Taken home by } \\
\text { employees }\end{array}$ & 6.9 & 20.5 & 14.3 & 11.1 & 10.0 & 10.0 & 19.4 \\
\hline $\begin{array}{l}\text { Selling to } \\
\text { consumers at } \\
\text { attractive prices } \\
\text { (shortly before } \\
\text { closing) }\end{array}$ & 3.4 & 2.6 & 2.9 & 2.8 & 5.0 & 3.3 & 3.2 \\
\hline $\begin{array}{l}\text { Using for preparing } \\
\text { other dishes }\end{array}$ & 3.4 & 2.6 & 5.7 & 5.6 & 5.0 & 0.0 & 6.5 \\
\hline Discarding & 27.6 & 17.9 & 5.7 & 16.7 & 15.0 & 23.3 & 9.7 \\
\hline
\end{tabular}

Table 5: Reasons for discarding food in catering establishments as stated by the respondents

\begin{tabular}{|l|c|c|c|c|c|c|c|c|}
\hline Reasons for discarding food & $\mathrm{N}$ & $\begin{array}{c}\text { Always and } \\
\text { Usually (\%) }\end{array}$ & Mean & Median & Mode & $\begin{array}{c}\text { Mode } \\
\%\end{array}$ & Kurtosis & SD \\
\hline Ill-considered purchase & 38 & 7.9 & 3.97 & 4.0 & 5.0 & 36.8 & -0.799 & 0.97 \\
\hline Too large a purchase & 39 & 12.8 & 3.82 & 4.0 & 4.0 & 43.6 & -0.553 & 0.97 \\
\hline Purchasing low quality products & 39 & 2.6 & 4.41 & 5.0 & 5.0 & 56.4 & 1.008 & 0.79 \\
\hline Improper storage conditions & 38 & 2.6 & 4.21 & 4.0 & 4.0 & 44.7 & 0.277 & 0.78 \\
\hline Preparing too much food & 40 & 22.5 & 3.62 & 4.0 & 5.0 & 30.0 & -1.397 & 1.15 \\
\hline Overlooking expiry date & 37 & 2.7 & 4.03 & 4.0 & 4.0 & 45.9 & -0.395 & 0.80 \\
\hline Lack of ides for other use of products & 39 & 5.1 & 4.56 & 5.0 & 5.0 & 74.4 & 2.943 & 0.85 \\
\hline Unqualified employees & 39 & 5.1 & 4.23 & 5.0 & 5.0 & 53.8 & -0.506 & 0.96 \\
\hline
\end{tabular}

1 - always, 2 - usually, 3 - sometimes, 4 - occasionally, 5 - never

Table 6: Results of descriptive statistics concerning consumers behaviour in relation to meals received in catering establishments

\begin{tabular}{|l|c|c|c|c|c|c|c|c|}
\hline $\begin{array}{l}\text { Consumer behaviour in } \\
\text { relation to meals }\end{array}$ & $\mathrm{N}$ & $\begin{array}{c}\text { Always and } \\
\text { Usually (\%) }\end{array}$ & Mean & Median & Mode & $\begin{array}{c}\text { Mode } \\
\%\end{array}$ & Kurtosis & SD \\
\hline Leaving "plate waste" & 41 & 19.0 & 3.22 & 3.0 & 3.0 & 41.5 & -0.881 & 0.88 \\
\hline Ordering half-portion meals & 40 & 0.0 & 4.33 & 4.0 & 5.0 & 47.5 & -0.863 & 0.73 \\
\hline
\end{tabular}

1 - always, 2 - usually, 3 - sometimes, 4 - occasionally, 5 - never

As the respondents pointed out, it is offering dishes with servings that are too large that constitutes the main reason for the so-called plate waste (73.8\% of answers). Further among cited replies are factors including ordering too many meals $(54.8 \%)$, inappropriate taste of dish (23.8\%), unpleasant atmosphere and finding an undesirable element in a dish, 
e.g. a hair or nail ( $7.1 \%$ equally).

Raw vegetable salads were the most frequently quoted products left by consumers on their plates $(17.1 \%$ of respondents indicated that they are "always" or "usually" left on plates) (Figure 1).

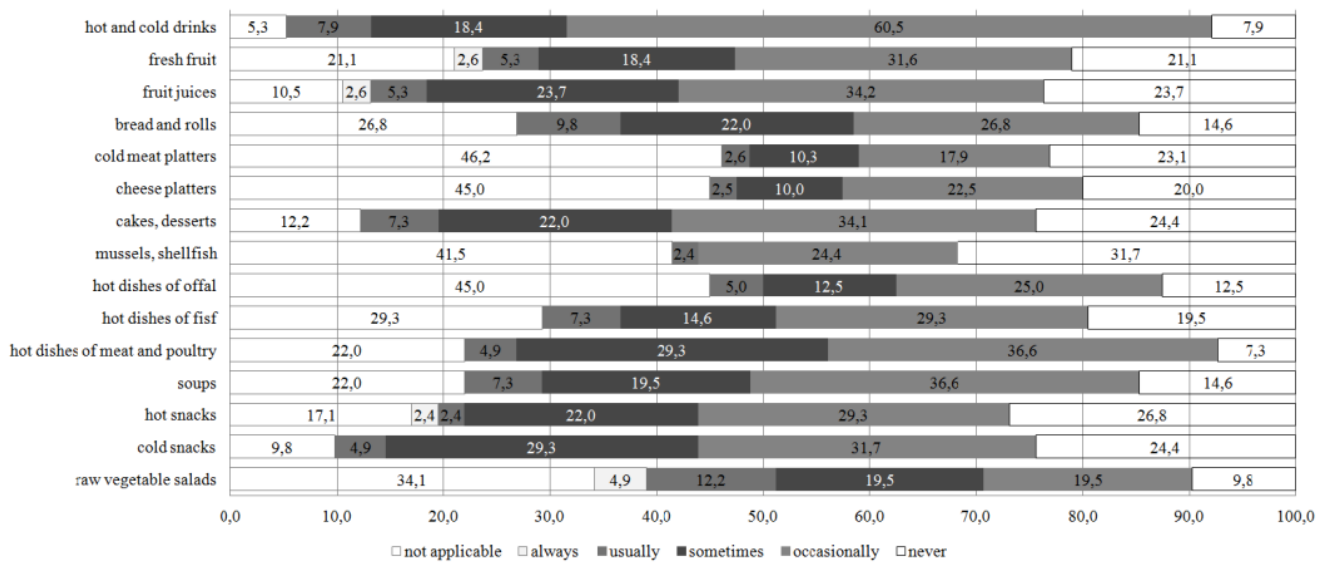

Figure 1: Frequency at which consumers leave their meals, the so-called plate waste

\section{Discussion}

\subsection{Organizational aspects related to food waste}

In Poland, the number of catering establishments is gradually increasing. In 2017, it was estimated to exceed 70.1 thousand, the majority of which operated in the private sector (98.7\%) ([Statistics Poland] GUS 2018). Along with the growth of the hotel and catering services sector, more and more waste is produced (Massow \& Mc Adams 2015), including food waste.

Although the respondents said they never or rarely buy products with short expiry dates and they quite systematically inspect the expiry dates of their stored products, it is the products past expiry dates, next to opened products with visible signs of spoilage, were among those most frequently thrown away. Indeed, these are products that should not be used for meal preparation. It was simultaneously noted that approximately $1 / 4$ of those questioned admitted that products which could be potentially used further, such as wilted fruit and vegetables and opened products without signs of spoilage, were discarded too. Likewise, Papargyropoulou et al. (2016) draw attention that in hotel catering it is fruit and vegetables that form a main category of food waste that could be avoided. It is important to determine which food groups are most often discarded when considering how to reduce this undesirable phenomenon, for it helps to point out which operational processes should be modified so that amounts of food wasted in a given establishment could be minimised (Filimonau \& de Coteau 2019). For instance, to cut the risk of discarding wilted fruit and vegetables, thought should be given to how to store and/or implement better production organization (planning of orders and menus). Pirani \& Arafat (2016) write about the proper method of warehousing fruit and vegetables as a strategy of minimising food waste. They draw attention to a number of hotels in the United Arab Emirates which store fruit 
and vegetables in wirebound crates so to allow air circulation and, at the same time, reduce the growth of microorganisms and spoilage processes.

More and more often, food waste is monitored by catering establishment owners, as the majority of them operate based on private equity. They are therefore aware that raw ingredient purchases account for a considerable share of operating costs. As analyses by Tomaszewska et al. have demonstrated (2015), the costs of purchasing raw materials constitute $35 \%$ of the average monthly operating costs of a catering establishment. For that reason, taking care of raw materials while they are warehoused as well as in other technological process stages is not surprising. As Pirani \& Arafat (2016) emphasise, many hotels that run catering business have procedures in place, which aim at minimising food waste related to spoilage/expired shelf life of foodstuffs, e.g. FIFO (First-In, First-Out), planning of dishes for the preparation of which raw materials with short expiry dates will be used. As Engstrom \& Carlsson-Kanyama emphasise, improper storage conditions and failure to apply the FIFO principle are important factors in the generation of food waste. In our own studies, the respondents asserted that preparing too much food was a main cause for throwing food away. Obviously, as was ascertained, surplus prepared dishes were in most cases stored at a refrigerator condition to next day. However, discarding the dishes that were not served was often given in answers. Silvennoinen et al. came to similar conclusions in their research (2012), acknowledging that most of the food wasted in Finnish catering establishments was due to preparing too many dishes which could not be stored or used to prepare other meals later. It is especially establishments where meals are served in the self-service system that find it difficult to estimate the necessary number of portions (Papargyropoulou et al. 2016; Pirani \& Arafat 2016).

\subsection{Consumer behaviour related to food waste}

The respondents admitted that about $1 / 5$ of customers leave partially uneaten meals on their plates (what is called plate waste). These form a type of food which cannot be reused whatsoever. Although this type of waste can be used to produce compost and energy (biogas plants), but, as Papargyropoulou et al. (2014) point out, the food waste hierarchy does not posit it as a method which is generally considered to be a good alternative to the food actually used for human consumption. In our own studies, 55\% of the respondents admitted their workplaces do not agree to sell half a portion. As few as $15 \%$ of the surveyed establishments offer the possibility of adjusting portion sizes in relation to all dishes they offer. Meanwhile, the research carried out by the UK's Sustainable Restaurant Association (2010) showed that British restaurants waste about $30 \%$ of food because of consumers who leave plate waste. Participants in the study by Okumus et al. (2020) indicated that in hospitality sector customers are the main source of food waste. The mass of plate waste generated is correlated with the form of food service provided. For example, the largest share of plate waste are observed after meals served at a self-service buffet in comparition to waiters service (Priefer et al. 2016).

The issue of food waste is more and more often discussed in the media. As a result, in their growing awareness, consumers take part in all different kinds of initiatives aiming to minimise food waste such as culinary workshops and cooking seminars. Yet to mitigate this adverse phenomenon in catering establishments, it is necessary to start communication with customers and talk to them (Marthinsen et al. 2012). It is far easier for catering 
establishment managers to implement technical and organisational solutions than to influence consumers themselves when it comes to their attitudes regarding certain issues (such as food waste). Some consumers are more eager to choose those establishments which serve large food portions. Only when a customer receives such a portion will they be satisfied with the service in a given establishment. In meeting this consumer group's expectations, a number of establishments offer large portion sizes with no possibility of modifying them.

As a matter of fact, as Kallbekken \& Saelen (2013) highlight, offering customers more flexibility in terms of their portion size preferences constitutes an important element of menu planning which may have an impact on the level of generated plate waste. There is one more significant dimension to portion flexibility pointed out by Wansink and van Ittersum (2013). Control over portion sizes may positively influence company image since consumers can view it as a measure to prevent obesity. Another solution worth considering is the size of tableware used to serve dishes (Kallbekken \& Saelen 2013).

To reiterate, food in the catering sector is discarded partially due to problems with estimating the number of portions/consumers. A solution to this issue which was promoted during the Restaurant Week (https://restaurantweek.pl) is worthy of attention. Under the slogans of \#RespectFood and zero waste, the event has been organised for several years in Poland. As emphasised by its organisers, owing to earlier reservation system which determines the number of participants and a chosen menu, "not a gram of food is wasted during the Festival" in the restaurants which take part.

\section{Conclusions}

Food waste in the context of increasing climate change and the diminishing natural resources of the Earth appears to be a challenge the contemporary world needs to face. Although, as literature data show, most food is wasted by consumers in households, the problem refers also to a large extent to collective consumption establishments. Food waste in the catering sector still remains an insufficiently studied issue, as catering establishment owners are often unwilling to disclose data pertaining to the subject. Many of them are afraid of inappropriate use of this type of information. No research of this kind has been conducted in Poland yet and it is therefore one of the challenges for the near future. However, to meet this challenge, it was first necessary to learn the causes of food waste in the Polish catering sector.

The obtained results are a starting point for further studies on the one hand and, on the other, they may also play a key role in preventing food waste in catering establishments. Areas for related to the behaviours of employees and management have been identified, which should be improved through educational activities. The results may be used to develop a code of good practices for catering establishment staff, which would aim at reducing food waste.

\section{Acknowledgements}

This publication has been developed under the contract with the National Center 
for Research and Development No Gospostrateg1/385753/1/NCBR/2018 for carrying out and funding of a project implemented as part of the "The social and economic development of Poland in the conditions of globalizing markets - GOSPOSTRATEG" program entitled "Developing a system for monitoring wasted food and an effective program to rationalize losses and reduce food wastage" (acronym PROM).

\section{References}

Berjan, S., Mrdalj, V., El Blali H., Velimirovic, A., Blagojevic, Z., Bottalico, F. Debs, P., Capone, R. (2019). Household food waste in Montenegro. Italian Journal of Food Science, 31, 274-287.

Engstrom, R., Carlsson-Kanyama, A. (2004). Food losses in food service institutions Examples from Sweden. Food Policy, 29, 3, 203-213.

FAO. Save Food: Global Initative on Food Loss and Waste Reduction. http://www.fao.org/savefood/resources/keyfindings/en/. Accessed 20/09/2019.

Filimonau, V., de Coteau, D.A. 2019). Food waste management in hospitality operations: A critical review. Tourism Management, 71, 234-245.

Gheribi, E. (2014). The structure of foodservice companies demand during tourist trips. Zeszyty Naukowe. Turystyka i Rekreacja, 2(14), 63-79.

GUS (Główny Urząd Statystyczny) (2018). Rynek wewnętrzny w 2017 r.

Gustavsson, J., Cederberg, C., Sonesson, U., van Otterdijk, R., Meybeck, A. (2011). Global Food Losses and Food Waste, FAO, Rome, Italy.

https:// restaurantweek.pl. Accessed 30/10/ 2016.

Ishangulyyev, R., Kim, S., Lee, S. H. (2019). Understanding Food Loss and Waste-Why Are We Losing and Wasting Food? Foods, 8, 297.

Kallbekken, S., Saelen, H. (2013). Nudging hotel guests to reduce food waste as a win-win environmental measure. Economics Letters, 119(3), 325-327.

Maciag,, A., Bobola, A., Górska-Warsewicz, H., Gębski, J. (2018). Assessment and Forecast of the Catering Sector's Financial Situation in Polish Entrepreneurs' Opinion and in the Market Development Perspective. Handel Wewnetriny, 1(372), 87-98.

Massow, M.V., McAdams, B. (2015). Table scraps: An evaluation of plate waste in restaurants. Journal of Foodservice Business Research, 18, 437-453.

Marthinsen, J., Sundt, P., Kaysen, O., Kirkevaag, K. (2012). Prevention of Food Waste in Restaurants, Hotels, Canteens and Catering. Nordic Council of Ministers, Copenhagen.

Okumus, B., Taheri, B., Giritlioglu, I., Gannon, M.J. (2020). Tackling food waste in all-inclusive resort hotels. International ournal of Hospitality Management, 88, 102543.

Papargyropoulou, E., Lozano, R., Steinberger, J.K., Wright, N., Ujang, Z.B. (2014). The food waste hierarchy as a framework for the management of food surplus and food waste. Journal of Foodservice Business Research, 76, 106-115.

Papargyropoulou E., Wright N., Lozano R., Steinberger J., Padfield R., Ujang, Z. (2016). Conceptual framework for the study of food waste generation and prevention in the hospitality sector. Waste Management, 49, 326-336.

Pirani, S.I., Arafat, H.A. (2016). Reduction of food waste generation in the hospitality industry. Journal of Cleaner Production, 132, 129-145

Priefer, C., Jörissen, J., Bräutigam, K.R. (2016). Food waste prevention in Europe - A cause-driven approach to identify the most relevant leverage points for action. Resources, Conservation \& Recycling, 109, 155165.

Silvennoinen, K., Katajajuuri, J.M., Hartikainen, H., Jalkanen, L., Koivupuro, H.K., Reinikainen, A. (2012). Food waste volume and composition in the Finnish supply chain: special focus on food service sector. Fourth International Symposium on Energy from Biomass and Waste. CISA Publisher, Italy.

Stancu, V., Haugaard, P., Lähteenmäki, L. (2016). Determinants of consumer food waste behaviour: Two routes to food waste. Appetite, 96, 7-17. 
Sustainable Restaurant Association (SRA). (2010). Too good to waste: Restaurant food waste Survey Report. https://docplayer.net/29065730-Too-good-to-waste-welcome-sustainable-restaurant-associationrestaurant-food-waste-survey-report-2010.html. Accessed 27/09/2019.

Tomaszewska, M., Bilska, B., Grzesińska, W. (2015). Ocena efektywności ekonomicznej zakładu gastronomicznego. Roczniki Naukowe Stowarzyszenia Ekonomistów Rolnictwa i Agrobiznesu, T. XVII, 5, pp. 297 - 301.

United Nations. Sustainable Development Goals. https://sustainabledevelopment.un. org/?menu=1300. Accessed 20/08/2019.

Wansink, B., van Ittersum, K. (2013). Portion size me: Plate-size induced consumption norms and win-win solutions for reducing food intake and waste. Journal of Experimental Psychology: Applied, 19(4), 320 332. 